\title{
Taking the Biographical Approach Seriously - What Does it Mean for the Concept of Biographicity?
}

\author{
Tomando en serio la aproximación biográfica. \\ ¿Qué significa esto para el concepto de biograficidad?
}

\section{Barbara Stauber ${ }^{1}$}

\begin{abstract}
The article starts from the dialectic relationship between «the biographicity of the social» and «the sociality of the biographical» - a relationship especially underlined in the works of Bettina Dausien (e.g. 2006). In her understanding, the biographical approach is far from assuming a completely intentional, rational, conscious subject, as has been frequently criticized by poststructural point of view (see Thon 2016). Instead, it is based on the assumption that the whole setting in which a biographical interview takes place, its specific historical context, the socio-economic conditions in which the interviewed person is situated as well as the dominant discourses which form the background of the whole situation, are to be considered in the analysis of this specific biographic reconstruction we later have at hands, when working in the transcript of an interview.

Starting from here, the contribution argues, that we have not only to look at «what» is reconstructed here, but also «how» this reconstruction is presented - this means: the performative aspects of how an interview as a whole is given by the interviewee, and how individual issues are presented within this interview. By this, the complex powerful social processes of «addressing» and «being addressed» come into the center of interest (Rose/Ricken, 2018).

Addressing and the way people let themselves «being addressed» (Althusser) - if and how they let themselves being addressed - this question opens up for processes of subjectivation, as has been conceptualized by Judith Butler and earlier by Michel Foucault: within subjectivation, people undergo a (powerful) process of submission, but within the same process and at the same time they become subjects. It is this paradoxical simultaneity of two movements - submission and becoming a subject - which makes the concept of subjection so fruitful as an analytical tool. Getting addressed is the one part of it (Althusser), but this is not determining the way in which people are turning around and are responding to the fact of «being addressed». Thus, the concept of subjection also gives space for the modifications, in which people could (and do) respond - and thus to their agency, and their (maybe subtle) subversion. Judith Butler would frame this with the concept of resignification. In the last part of this article, it will be shown how close this idea of resignification comes to the concept of biographicity. Both are hinting to the transformative potential of every educational process.
\end{abstract}

\section{Keywords}

Biograficity, sociality, poststructural criticism, performativity, transformative aspects, education.

\section{Resumen}

El artículo parte de la relación dialéctica entre «la biografía de lo social» y «la sociabilidad de lo biográfico», una relación especialmente subrayada en los trabajos de Bettina Dausien (por ejemplo, 2006). Según su comprensión, el enfoque biográfico está lejos de asumir un sujeto completamente intencional, racional y consciente, como ha sido frecuentemente criticado por el punto de vista postestructural (ver Thon 2016). Por el contrario, se basa en el supuesto de que todo el entorno en el que tiene lugar una entrevista biográfica, su contexto histórico específico, las condiciones socioeconómicas en que se encuentra la persona entrevistada y los discursos dominantes que forman el trasfondo de la totalidad situación, deben ser considerados en el análisis de esta reconstrucción biográfica específica que luego tendremos que manejar cuando trabajemos en la transcripción de una entrevista.

A partir de aquí, la contribución argumenta, que no solo tenemos que ver «qué» se reconstruye aquí, sino también «cómo» se presenta esta reconstrucción, esto significa: los aspectos performativos de cómo una entrevista en su conjunto es concedida por el entrevistado, y cómo se presentan los problemas individuales en esta entrevista. Con esto, los complejos y poderosos procesos sociales de «abordar» $\mathrm{y}$ «ser abordado» entran en el centro de interés (Rose/Ricken, 2018).

1 Barbara Stauber. Universität Tübingen; barbara.stauber@tuebingen.de. 
El abordaje y la forma en que las personas se dejan «abordan» (Althusser) -si y cómo se dejan abordar- esta pregunta se abre a los procesos de subjetivación, como ha conceptualizado Judith Butler y antes Michel Foucault: dentro de la subjetivización, las personas se someten a un (poderoso) proceso de sumisión, pero dentro del mismo proceso y al mismo tiempo se convierten en sujetos. Es esta simultaneidad paradójica de dos movimientos, la sumisión y el convertirse en un sujeto, lo que hace que el concepto de sujeción sea tan fructífero como una herramienta analítica. El abordaje es una parte de esto (Althusser), pero esto no determina la forma en que las personas están dando la vuelta y están respondiendo al hecho de que «se aborda». Por lo tanto, el concepto de sujeción también da espacio para las modificaciones, en las que las personas pueden (y responden), y por lo tanto a su agencia, y su subversión (tal vez sutil). Judith Butler enmarcaría esto con el concepto de resignificación. En la última parte de este artículo se mostrará cuán cerca está esta idea de resignificación del concepto de biográficidad. Ambos insinúan el potencial transformador de cada proceso educativo.

\section{Palabras clave}

Biograficidad, sociabilidad, crítica postestructural, performatividad, aspectos transformadores, educación. 


\section{1. «The biographicity of the social» and «the sociality of the biographical» - the ap- proach of Bettina Dausien and others}

First, this article wants to point out a central misunderstanding of biographical approaches: This is the idea of highly individual stories, constructed by individual biographers, for which biographical analysis should serve as analytical tool. Even if biographical analysis (above all, when contrasted with other methodological approaches) is often put like this, none of the more prominent approaches, be it the one of Fritz Schütze, be it the one of Gabriele Rosenthal, be it the one of Bettina Dausien or of Andreas Hanses, would agree with such a limited understanding. None of these approaches would isolate biographical narratives from the societal context in which they are generated. All these approaches would consider that the biography is located within a specific historical situation. Partly (e.g. in the work of Andreas Hanses) biography is explicitly marked as a phenomenon of a specific historical period, in which the telling of a biography has become something quite normal, if not socially expected ${ }^{2}$.

Perhaps we could find the most explicit position in this regard in the older texts of Bettina Dausien: According to her, a biography is to be seen as

"... a product of processes of social construction, as a, social matter of fact" in modern societies, which
is to be historically qualified according to different cultural and social contexts. To the same extent
as one not simply, has' a gender, one not simply, has" a biography. A biography is rather generated
by abstract and concrete social images; by expectations from the closer social surroundings and by
institutional schedules of expectations, which vary according to social and cultural milieus; by setting
the course due to structural conditions, which could be reconstructed as concrete material, juridical and
social restrictions of the individual scope of agency; and last but not least by the reflexive achievement
of the subjects themselves: without theirproper biographical work neither social agency would be concei-
vable, nor social structure would be reproduced.» (Dausien, 1999:238).

This understanding of biography is reflecting on social context, discourses and historical conditions. Thus, as Andreas Hanses put it, «biographical narrations are not in contradiction to social analysis, moreover, (...) subjective presentations of experiences rather facilitate crucial insights in the meaning and relevance of social worlds» (Hanses, 2008:13). Biographies therefore could be put as «socialized subjectivity» (Bourdieu/Wacquant, 1996:237) - they represent also processes of doing gender, doing ethnicity, doing class and therefore are expressions of a «social in general» (Hanses, 2008:13). Thus, everything that could be related with an institutionalized life course - aspects of social and historical situatedness, aspects of context-specific normalities (due to specific welfare regimes, gender regimes, migration regimes, see Walther 2017) - could be represented respectively read within biographies. This representation could appear in an affirmative or confirming way, it could appear in a critical or subversive way. But it would always be like that: interviewees have to position themselves with regard to a specific interview setting, they have to deal with ascriptions, they are called into discourses, and are reproducing (or modifying) them even if they are presenting (presumingly) a highly individualized story. This is all social data.

However, and this would be my first point: we only can get access to these social realities via such reconstructions and the respective practices of performances, which would «bring them on stage», so to say (zur Auffübrung bringen). And at the same time, we have to accept that we would not be able to get any further to any kind of «deeper reality» than analyzing these practices of performing/of reconstructing/

\footnotetext{
2 In my own work (Stauber 2004; Stauber 2014, Stauber \& Walter 2016) I could show how young respondents in a way offensively use the stage offered by the interview setting - a phenomenon, which I would not separate from a societal context in which presenting oneself has become a common demand.
} 
of «giving an interview.» This is marking a limit for social analysis (which nevertheless can be rich). Here, we already could refer to the suggestion of Nadine Rose (2012) about how to deal with this limit: this is, to look much more at the performative aspects of giving an interview (see below, 3.). And this idea would, perhaps, stand in a certain contrast with the idea of Gabriele Rosenthal who wants to confront the told biography with the experienced (real?) life. This idea of two realities which could be confronted with each other, perhaps has been a bit misleading, because it insinuated the possibility of getting access to a quasi "objective" reality of an individual life. On this, not only poststructuralists but a lot of qualitative researchers as well, would be skeptical/critical.

\section{Poststructural criticism towards biographical approaches}

However, the criticism of poststructuralists even goes beyond pointing to the problematic suggestion of the «two realities». It asks: isn't it a kind of resurrection of the (already declared dead) autonomous self-reflected subject if we concentrate so much on the individual's biographical stories? Isn't it namely «the concept of biographical obstinacy», which is «calling up a subject (or only produce it) which long time ago has been deconstructed. This would afford a new definition of subversivity and its roots» (Thon 2016: 185).

However, I would go with Christine Thon and Nadine Rose in saying that taken biography as explained above, biographical analysis offers us a bundle of possibilities to encounter this critique:

Referring to Dausien, Rothe and Schwendowius (2016: 31), there are relevant (and always social) contexts in which the reconstructing of biographies is taking place: there is the story of one's life (1), the social-institutional framework and related discourses (2) but also the situation in which the interview is taking place (3). These different contexts not only influence the interview, but represent a constitutive framework for it: they create the construction of biographies and therefore are relevant, if not crucial aspects for analysis.

Biographies thus are not to be understood as simple «copies» of reality, but they themselves generate and shape social realities. This is very much in line with the generative idea of a praxeological understanding of reality: realities are made by practices, and it is only by analyzing practices that we can get a clue about social realities. Daniel Wrana, in adapting the Foulcaudian discourse theory, makes the point that practices always have to be considered as discoursive practices (Wrana 2015). According to him, realities in a way are done by these discoursive practices, and we cannot systematically «look behind» (zurückschanen) them. If we follow him, this indeed would make it necessary to shift the focus.

If we regard biography as a contextualized and situated construction, it brings us above all to look at the way in which the talking subjects are constructing their narrations. The latter are to a big extent testimony of HOW people are becoming subjects, i.e. of processes of subjectivation. Obviously, interviewees pick up the options given by the interview and use its impulses for developing an own story - insofar they always refer to a certain extent to predominant discourses which are (re)generated within the interview. And: they would draw back to other occasions of biographical story telling they have experienced in their lives up to then. Here, we have to call in mind the three contextual aspects of Dausien, Rothe and Schwendowius as outlined above: (1) there are very different experiences in telling the story of one's life: If we consider for example a young refugee (who is frequently asked about his or her migration story), a young person in foster care (who is frequently asked about his or her family and institutional «career»), 
or a young «normal» kid doing this for the first time in his or her life, we will see, that the opener of a biographical interview could relate to very different experiences of biographical story-telling; the request to tell the story of one's life could even trigger traumatic experiences for example being interviewed by the police in a crucial situation of forced migration. Biographical story-telling always is situated in a concrete historical context in which this experience is far away from being something neutral. (2) Also, the socialinstitutional framework in which the biographer manages his or her life at the moment (or in the past or in the future) is an important context for telling the own story. Again, specific contexts in which $\mathrm{S} / \mathrm{He}$ for example is addressed as a client of counselling, or as a participant of a specific training measure for unemployed, or as a person living on social benefits, have to be taken into account. S/He S/He also could feel to be «called into» dominant discourses (Hall, 1985, 1996) and make a statement in which to position her/himself 3 . (3) But also the situation in which the interview is taking place is to be considered as a highly relevant social context: is it taking place within a specific institutional setting? Or has it been enabled by a contact person who represents a specific institution, e.g. a school or an agency of social work? Taking these aspects into account is far from assuming an autonomous subject who is «simply» telling his or her life.

In this regard, Judith Butler had made her big point in saying that becoming a subject and undergoing processes of subjectivation are belonging closely to each other, or better taken: they are emerging in the same process (an idea, she had picked up from Foucault, but also from Althusser):

"We are used to thinking of power as what presses on the subject from the outside, as what subordinates, sets underneath, and relegates to a lower order. This is surely a fair description of part of what power does. But if, following Foucault, we understand power as forming the subject as well, as providing the very condition of its existence and the trajectory of its desire, then power is not simply what we oppose but also, in a strong sense, what we depend on for our existence and what we harbor and preserve in the beings that we are. The customary model for understanding this process goes as follows: power imposes itself on us, and, weakened by its force, we come to internalize or accept its terms. What such an account fails to note, however, is that the «we» who accept such terms are fundamentally dependent on those terms for «our» existence. Are there not discursive conditions for the articulation of any «we»? Subjection consists precisely in this fundamental dependency on a discourse we never chose but that, paradoxically, initiates and sustains our agency.» (Butler, 1997: 2).

Consequently - and this is the productive aspect of the above poststructuralist critique - the newer approaches to biographical analysis (especially: Jergus, Ricken, Rose, Thon and others) relate this idea of becoming a subject by subordination to the biographical interview itself: the latter is to be seen as a specific setting in which processes of subjectivation can be analyzed perfectly. The biographical interview assumes first of all that having a biography is something self-understood, and calls the interviewee into this assumption. It is already here, that we have a perfect example for subjectivation as put in the above quote: «Subjection consists precisely in this fundamental dependency on a discourse we never chose but that, paradoxically, initiates and sustains our agency» (italics by BS). It then calls for specific narrations - and the interviewee tries as best as $\mathrm{S} / \mathrm{He}$ can to deliver these. However, $\mathrm{S} / \mathrm{He}$ also could make other turns than expected, e.g. she could instead of narrating try to draw the interviewer into a discussion... Also this represents a perfect example for the latter part of the above quote: «Subjection consists precisely in this fundamental dependency on a discourse we never chose but that, paradoxically, initiates and sustains our agency» (italics by BS).

3 This could happen rather implicitly. E.g, when doing my study on young adults and their youth cultural practices in goa-trance, in a period where the consumerism of extasy has been high on the public agenda, my respondents, without being asked, positioned themselves to extasy consumption. 
Here, the paradoxical simultaneity of the two movements within subjection has to be highlighted. According to this paradoxical simultaneity, processes of «becoming a subject by subordination» are critical towards dominant discourses - they put their finger onto the whole plethora of othering (McCall 2005), stigmatizing, discriminating adscription and labeling - thus, it is by these subjectivation processes, that gendering/othering processes, process of doing difference are to be assumed (and correspondingly could be analyzed). In this regard, biographical analysis is (with Nadine Rose and her reference to Bettina Dausien) always critical social research - critical above all towards powerful societal discourses. This allows linking it with a critical research on «subjectivation» which has become prominent above all in German educational sciences. This is the one aspect of subjectivation.

The other aspect is, that not only such processes of doing difference by iteration can be reconstructed - also hints to agency could be identified wherever individuals do not simply reproduce and repeat societal norms and differentiations in an ordinary way, but always modify them to a smaller or larger extent (I will come back to this aspect, which Butler has called resignification, in point 4.).

\section{The double performativity which is represented by an interview}

Thus, the praxeological turn in reading the transcript of an interview seems to be crucial, because it prevents from solely focusing on the «What» and instead shifts the attention to the «How» of narrative practices of doing biography: With this turn, the interview (as a social setting) is regarded as a stage for performing selves, and this stage and its fabric - how is it positioned? What is its relevance? - has to be considered in any analysis which takes «appellation» into account. Praxeological considerations get methodologically fruitful, if not indispensable, in this regard (Ricken et al., 2017:205), as far as they allow thematizing the generating issues within the setting of a biographical interview. As an example: Agency, then, is not simply taken for granted, instead one could ask: which is the framing in which something is generated/ done/educed as agency? What are the socio-material conditions for narrating/of the narration? E.g., to be positioned as somebody who is «living on benefits» - what does this mean in a situation of «giving an interview»? Or: to be positioned as former drug addict: how would this shape your performance when asked to tell the story of your life? All these conditions are about facilitating (or non-facilitating/limiting) a space for ideas and visions, a space for differing from dominant discourses, etc.

If we agree, that we have not only to look at «what» is reconstructed here, but also at «how» it is presented, the performative aspects of how an interview as a whole is given, and how individual issues are presented, come into the center of interest. By this, the complex social scenario of «addressing», re-adressing and being addressed has to be considered, as Nadine Rose and Norbert Ricken formulate in their «analysis of addressing», which they suggest as a tool to do subjection analysis (Rose/Ricken, 2018).

We could argue that it is essential for such a biographical approach to regard the interview respectively the biographical text generated by it, as performance within these scenarios of (re)adressing (Rose, 2012: 119). By this, a double performativity has to be considered:

"to look at a biographical text as a performance is in my view helping to come closer to analyse its double performativity: on the one hand, because it makes clear that the text as a performance is only sketched and told for a specific situative reason (and for a specific underlying research interest). This has to be understood as a necessarily selective perspective on the potential of a tellable life in a concrete moment. On the other hand, this performative perspective makes visible that the narrative presentation itself is to be regarded as a social practice in the framework of social conventions. The narrative 
presentation which I would put as a performance, therefore can be regarded with regard to its verbal embodiment/organisation (Ausgestaltung): what is told, and how? Understood as a performance, this embodiment/organisation (Ausgestaltung) also can be looked at with regard to how and with which effects figures, practices and evaluations are related to: with each other, i.e. with regard to the Dramaturgie this embodiment/ organisation (Ausgestaltung) enfolds.» (Rose, 2012: 119).

With this suggestion (the biographical storytelling as performance) Nadine Rose tries to do justice to the double performativity of biographical analysis (Rose, 2012: 234, Herv. i. O.):

"On the one hand, this underlines that it [biographical storytelling, BS] only takes place, only is developed, only is presented and only is transcribed because of this specific situative inducement and has to be read as a specific perspective on the told life to a specific moment (the performativity of biographical research). On the other hand, because this makes visible that the performance itself in its lingual figurality is executing a social practice, in which actors, practices, descriptions, evaluations etc. are related with each other in a specific way and are constituted as a - not necessarily coherent - overall relationship (Gesamtzusammenhang) (performativity of biographical storytelling).» (Rose, 2012:234).

To focus on the performance and its effects, by the way, is preventing rather effectively from the intention/ and the believe to achieve any «subject behind» (ibid: 120). On the contrary: we cannot assume that there is a strict continuity or linearity between intentions, expressions and their effects. I.e. subjectivation is nothing linear or predictable. «Moreover, the appropriation or non-appropriation resp. the incorrect appropriation (Butler 1997) of the norm which is called up within the process of appellation is itself a central element of the whole process of subjectivation» (Ricken et al.,2017: 207).

To sum it up: In this version of biographical analysis the basic idea is much more focusing on the performative aspects compared with other biographical approaches:

- It is putting the question of «HOW» in the centre of analysis - in the way that it takes serious what is documented by a specific performance (see also Amling\&Geimer, 2017).

- It is considering bodily aspects (bodily practices are «telling» different stories: here, the habitus as the set of well-known incorporated practices has to be taken into account, as well as the unaccountable bodily reactions in the contingencies of the moment. Both, habitus and spontaneous bodily reactions, are going beyond the spoken word. They also bring vulnerability in our mind (Butler, 2016).

- It is showing rituals/ritualisations, but also their fragility, their susceptibility to trouble (Störanfälligkeit) and their irregularities.

- It is keen on contradictions, on misalignments, on aberrantphenomena in performative practices (see Rose, 2012; Stauber/Walter, 2018).

Thus, the focus on performance is especially insightful and «telling» with regard to the contingencies, and therefore also the transformability of social orders. If this section has focused above all on the processes of appellation/addressing, the next section wants to underline - with Butler and Rose - that there has always to be a kind of response to this appellation/addressing. However, this response is no automatism at all (see also Balzer/Ludewig, 2012), nor is it determined in its mode. And this is opening up for the theoretical option of transformation. 


\section{The transformative perspective}

How are contexts of addressing evolving, how are they becoming effective? How, in my research field, are we calling our interviewees into the topic of transitions? - and how do we have to consider this powerful process, but also its limitations?

"So it will not be enough to isolate and identify the peculiar nexus of power and knowledge that gives rise to the field of intelligible things. Rather, it is necessary to track the way in which that field meets its breaking point, the moments of its discontinuities, and the sites where it fails to constitute the intelligibility it promised. What this means is that one looks for the conditions by which the object fields is constituted as well as the limits of those conditions, the moment where they point up their contingency and their transformability.» (Butler, 2004: 215f.).

Judith Butler has illuminated this consideration predominantly (but not solely) with regard to gender:

"What this means for gender, then, is that it is important not only to understand how the terms of gender are instituted, naturalized, and established as presuppositional but to trace the moments where the binary system of gender is disputed and challenged, where the coherence of the categories are put into questions, and where the very social life of gender turns out to be malleable and transformable.» (Butler, 2004: 2016).

This idea of course can be enlarged for other categories. The important point is here to characterize biographical interviews as a site in which this can get visible:

«in biographical studies it could be shown again and again that biographers are being addressed and called into discourses, but also that what they are doing with the positionings being made available - i.e. how they give them content, how they shape them, how they reject them - is far more obstinate, self-determined or simply far more complex and chaotic than would have been foreseen by addressing/ interpellation.» (Spies, 2017: 71).

Biographical reconstructions thus could be understood as sites in which discourses are invoked or passed over, they represent sites for resignifying such discourses (Rose 2012:118).

«with the concept of «resignification» Butler is marking exactly those practices which are able to shift the discoursive significances and norms, by not reiterating them in the way they should be reiterated.» (Rose, 2012: 117).

This core concept of resignification is based on the simple idea that each appellation needs to be responded by some kind of reaction, some kind of «turning around» - and it is not determined if and how subjects let themselves being addressed (Rose). The way they turn around, metaphorically speaking, rather than being determined, is open for modification, for obstinacy, for subversion. Thus, transformativity in principle is becoming thinkable by resignification. The important point is here, and this is already indicated by the term «resignification», that all these options of responding still are related to the appellation, or better: they are provoked, they are constituted by appellation. The latter therefore not only has a submitting but a highly generating and enabling function.

This also could include that what has been ignored by dominant discourses, or revealed to be not intelligible, is brought into or inscribed in these discourses. This is the example of queer policies which 
has brought into the gender discourse what has not being represented so far - queer life styles, trans* life styles etc.

This transformative aspect in a way has always being one reason for the attractivity of biographical analysis for (qualitative) educational research. In this (qualitative) educational research a speficic understanding of Bildung is raised, which has nothing to do with formal achievements within the educational system, but which focuses on the way how the educational subject would change the world - and selfrelations. This transformation (which is not simply «learning», but a real change in views and relationship) would be in the core of what these colleagues (Marotzki, Kokemoor, Koller) would call «Bildung».

\begin{abstract}
«Butler's reference to a concept of iteration, which does not mean identical reproduction, but temporalization, displacement and change, is to be understood as a search for the possibilities and the options of transformative processes not beyond powerful discoursive networks but within the conditions, which let individuals become subjects. Bildung understood as a transformative procedure in which new figurations of world- and self-relations are constituted would be what Butler called misappropriation or resignification and (...) as «permanent political promise» of certain concepts and as potential «acts of resistance.» These are also to be understood as a potential for processes of Bildung which would consist in new articulations of preliminary and changeable identities, which pick up ascriptions of dominant discourse but resignify, displace respectively change them in a way which would open up for new options of agency.» (Koller/Rose 2012: 92f.).
\end{abstract}

The locus in which «Bildung» as a transformative process potentially can be made visible, is the biographical interview - and at the same time this is a methodological challenge to really show processes within these representations we have at hand when working with an interview transcript ${ }^{4}$. The last section wants to discuss the proximity of biographicity to these considerations - perhaps it could be regarded as one approach to make the transformation of world- and self-relations visible.

\title{
5. What would this mean for the concept of biographicity?
}

The last section wants to show how closely this transformative idea of resignification is related with the original idea of «biographicity». Biographicity has been often used to describe a process in which the late modern individual is re-framing the turbulences of life, especially new (and potentially critical) events (life events, but also historical and societal events) in order to make them matching with the biography which has been told so far:

Partly, biographicity has been turned into a «key competence within late modernity» - by Peter Alheit himself - which however evokes again the misleading idea of a strong and competent and fully rational subject. However, in the argumentation of this article, we would regard biographicity rather as a mode in which an ever new social reality is appropriated - a mode which is always open for transformation. This means: that we assume that whatever we could identify in the transcript of an interview, would be

- a negotiation process

- an explanation process for (recently) happened

- a legitimation process

4 The methodological challenge related with «analyzing educational processes» has been deeply discussed e.g. in a workshop of Christine Wiezorek and Matthias Grundmann (see Grundmann/Wiezorek 2013) 
- a matching process

- a resignifying process.

And this all happens in the contingencies of the moment of the concrete interview.

Resignification is the practice in which biographicity is becoming visible - as responding to always changing social contexts and discourses, and at the same time as «doing»/reproducing these social contexts and discourses. This is including affirmative as well as subversive moments within the practices of biographical story-telling. Biographies would not always be the place for resignifications, but they always could.

But again: those resignifications do not so much refer to the content (WHAT has been said?) but rather to the performative practices of giving an interview, of presenting oneself, of reacting to specific appellations within the interview etc. In these practices biograficity could be made visible. This would mean to enlarge the repertoire of interview analysis by aspects of the documentary method and also by ethnographical aspects (see Stauber/Walter, 2017).

To sum it up: As soon as the setting of an interview is regarded as well, and as soon as we are not only analyzing «statements» but also «statings», biographical analysis

- is enlarged towards / in direction to praxeology

- is drawn back to practices rather than to the intentions of a subject (Thon, 2015; Rose, 2017),

- has a backup by performation theory (performing selves),

- and is able to take into account the powerful links and discourses, into which interviewees (and interviewers) are permanently «called in.» ${ }^{5}$

Understood and carried out like that, biografical analysis can be used to «deconstruct discoursive effects of power on those subjects who are performing in the text, by analyzing processes of subjectivation respectively of subject constitution within the text» (Rose, 2012: 120).

Addressing and the way people let themselves being addressed (Althusser) - if and how they let themselves being addressed - this perspective not only up for the processes of subjection in the sense of submission by which subjects became subjects, but also for their agency, their resistance, their (maybe subtle) subversion. This could be located in the concept of resignification, which is quite close to biographicity, and which hints to the transformative potential of every educational process.

\section{Bibliographic references}

Alheit, Peter; Dausien, Bettina (2000): “Biographicity” as a basic resource of lifelong learning” in Peter Alheit (ed.): Lifelong Learning inside and outside schools, Roskilde: Roskilde University, University of Bremen and University of Leeds.

Alheit, Peter; Dausien, Bettina (2002): "Lifelong learning and 'biographicity'. Two theoretical views on current educational changes" in Bron, Agnieszka; Schemmann, Michael (eds.): Social Science Theories in Adult Education Research. Bochum Studies in International Adult Education. Münster, Hamburg, London: LIT Verlag.

5 For example in our big research project «doing transitions» (www.doingtransitions.org) we have to consider «transition» (especially formal transitions) also as a powerful discourse with in fact separating logics (before/after; successful/failing), onto which individual (informal) transitions could be understood as a response, which might represent a solution, but which also might turn the whole issue into something even more complicated. 
Amling, Steffen; Geimer, Alexander (2016): “Techniken des Selbst in der Politik - Ansatzpunkte einer dokumentarischen Subjektivierungsanalyse”. FQS. Forum Qualitative Sozialforschung, Jg. 17, H. 3, online unter: www.qualitative-research.net/index.php/fqs/article/view/2630/4037\&nbsp;

Balzer, Nicole; Ludewig, Katharina (2012): "Quellen des Subjekts. Judith Butlers Umdeutungen von Handlungsfähigkeit und Widerstand” in Ricken, Norbert; Balzer, N (Vorname) (eds.): Judith Butler: Pädagogische Lektüren. Wiesbaden: Springer VS.

Bourdieu, Pierre; Wacquant, Loïc, J. D. (1996). Reflexive Anthropologie. Frankfurt: Suhrkamp.

Butler, Judith (1997). The Psychic Life of Power. Theories in Subjection. Stanford: Stanford University Press

Butler, Judith (1997). Exitable Speech. A Politics of the Performative. New York: Routledge.

Butler, Judith (2004). Undoing gender. New York: Routledge.

Butler, Judith (2009). Die Macht der Geschlechternormen und die Grenzen des Menschlichen in Postskriptum zu Sprechakten und zur Übertragung.(Verlag, Ort) (276-280).

Butler, Judith (2016). Anmerkungen zu einer performativen Theorie der Versammlung. (Ort): (Verlag).

Dausien, Bettina (1996). Biographie und Geschlecht. Zur biographischen Konstruktion sozialer Wirklichkeit in Frauenlebensgeschichten. Bremen: Donat.

Dausien, Bettina (1999): “'Geschlechtsspezifische Sozialisation’ -Konstruktiv(istisch)e Gedanken zu Karriere und Kritik eines Konzepts" in Dausien, Bettina; Herrmann, Martina; Oechsle, Mechthild; Schmerl, Christiane; Stein-Hilbers, Marlene (Hrsg.): Erkenntnisprojekt Geschlecht. Feministische Perspektiven verwandeln Wissenschaft. Opladen: Leske + Budrich.

Dausien, Bettina (2008). Sozialisation - Geschlecht - Biographie. Theoretische Diskurse und Forschungsperspektiven. Wiesbaden: VS Verlag für Sozialwissenschaften.

Dausien, Bettina; Rothe, Daniela; Schwendowius, Dorothee (eds.) (2016): Bildungswege. Biographien zwischen Teilhabe und Ausgrenzung. Frankfurt, New York: Campus.

Grundmann, Matthias; Wiezorek, Christine (2013): "Einleitung zum Themenheft: Bildung und/oder Sozialisation?”, Zeitschrift für Soz̧iologie der Erziebung und Soz̧ialisation (ZSE) (33) Heft 2: 115-118.

Hall, Stuart (1985): "Signification, representation, ideology: Althusser and the post-structuralist debate". Critical Studies in Mass Communication, 2(2), 91-114.

Hall, Stuart (1996): "Who needs identity", Questions of Cultural Identity. Sage, 1-17.

Hanses, Andreas (2008): "Biografie" in Hanses, Andreas, Homfeldt, Hans Günther (eds.): Lebensalter und Soziale Arbeit 1: Eine Einführung. Baltmannsweiler: Schneider Verlag Hohengehren.

Jergus, Kerstin (2014): "Die Analyse diskursiver Artikulationen. Perspektiven einer poststrukturalistischen (Interview-)Forschung” in Thompson, C.; Jergus, K.; Breidenstein, G. (eds.): Interferenzen. Perspektiven kulturwissenschaftlicher Bildungsforschung. Weilerswist.

Koller, Hans-Christoph (2017): "Bildung as a Transformative Process" in Anna Laros, Thomas Fuhr, Edwar W. Taylor (Eds.): Transformative Learning Meets Bildung. An International Exchange. Rotterdam/ Boston/Tapei: Sense 2017. 
Koller, Hans-Christoph , Rose, Nadine (2012): "Interpellation - Diskurs - Performativität. Sprachtheoretische Konzepte im Werk Judith Butlers und ihre bildungstheoretischen Implikationen" in Nicole Balzer, Norbert Ricken (eds.): Judith Butler. Pädagogische Lektüren. Wiesbaden: Springer VS.

McCall, Leslie (2005): “Managing the Complexity of Intersectionality”, Sings, (Spring), 1771-1800.

Mecheril, Paul (2014). Subjektbildung. Interdisziplinäre Analysen der Migrationsgesellschaft. Bielefeld: transcript

Ricken, Norbert; Rose, Nadine; Kuhlmann, Nele; Otzen, Anne (2017): "Die Sprachlichkeit der Anerkennung. Eine theoretische und methodologische Perspektive auf die Erforschung von "Anerkennung", Vierteljahresschrift für wissenschaftliche Pädagogik, 93 (2), 193-235. Paderborn: Verlag Ferdinand Schöningh,

Rieger-Ladich, Markus (2012): "Judith Butlers Rede von Subjektivierung. Kleine Fallstudie zur 'Arbeit am Begriff”" in Ricken, N.; Balzer, N. (eds.): Judith Butler: Pädagogische Lektüren. Wiesbaden: Springer VS.

Rose, Nadine (2012): "Subjekt, Bildung, Text. Diskurstheoretische Anregungen und Herausforderungen für biografische Forschung” in Ingrid Miethe, Hans-Rüdiger Müller (eds.): Qualitative Bildungsforschung und Bildungstheorie. Opladen, Berlin, Toronto: Verlag Barbara Budrich.

Rose, Nadine; Ricken, Norbert (2018): "Interaktionsanalyse als Adressierungsanalyse - eine Perspektive der Subjektivationsforschung” in Martin Heinrich, Andreas Wernet (eds.): Rekonstruktive Bildungsforschung. Zugänge und Methoden. Wiesbaden: Springer VS.

Stauber, Barbara; Walter, Sibylle (2018): "Ugendkultureller Alkoholkonsum. Forschungs- und Praxiszugänge zu Adressat_innen Sozialer Arbeit auf der Grundlage der Dokumentarischen Methode” in Ralf Bohnsack, Sonja Kubisch, Claudia Streblow-Poser (eds.): Soziale Arbeit und Dokumentarische Methode - Methodologische Aspekte und empirische Erkenntnisse. Wiesbaden: Springer VS.

Thon, Christine (2016): "Biografischer Eigensinn - widerständige Subjekte? Subjekttheoretische Perspektiven in der Biografieforschung", Zeitschrift für Pädagogik, 62 (2).

Walther, Andreas (2017). Regime Papier Neckarel\%:

Wrana, D.; Langer, A. (2007): “An den Rändern der Diskurse. Jenseits der Unterscheidung diskursiver und nicht-diskursiver Praktiken”, Forum Qualitative Sozialforschung, 8(2), Art. 20.

Wrana, Daniel (2012): "Diesseits von Diskursen und Praktiken. Methodologische Bemerkungen zu einem Verhältnis" in Friebertshäuser et al., (eds.): Feld und Theorie. Herausforderungen erziehungswissenschaftlicher Ethnographie. Leverkusen: Budrich.

Wrana, Daniel (2015): “Zur Methodik einer Analyse diskursiver Praktiken” in Schäfer, F., Daniel, A./ Hillebrandt, F. (eds.): Methoden einer Soziologie der Praxis. Bielefeld: transcript.

\section{Biographical note}

Barbara Stauber es miembro del Instituto de Ciencias de la Educación de la Universidad Eberhard Karls de Tübingen. Imparte ciencias de la educación, con especialización en pedagogía social. Ha desarrollado proyectos de investigación sobre procesos de elección y transiciones entre la formación y el trabajo. 